\title{
ERRATUM
}

\section{Erratum to: Perceptions and Preferences of Two Etanercept Autoinjectors for Rheumatoid Arthritis: A New European Union-Approved Etanercept Biosimilar (Benepali ${ }^{\circledR}$ ) Versus Etanercept $\left(\right.$ Enbrel $^{\circledR}$ ) - Findings from a Nurse Survey in Europe}

Kunal Thakur · Anna Biberger · Alexandra Handrich · Mourad Farouk Rezk

Published online: September 29, 2016

(C) The Author(s) 2016. This article is published with open access at Springerlink.com

Erratum to: Rheumatol Ther (2016) 3:77-89

DOI 10.1007/s40744-016-0035-1

The last sentence within the last paragraph of the section 'Nurse Opinions on Patient Preference for Autoinjector and Attributes that Drive Nurse Choice of Autoinjector' is incorrect.

The correct sentence should read as follows:

Among the nine nurses who indicated a preference for the Enbrel MYCLIC autoinjector, the most common reasons given were "easy to operate" $(n=6)$, followed by "easy to grip" $(n=5)$, "audible feedback" $(n=4)$, and "concealing the injection needle" $(n=4)$ (Fig. 5).

The online version of the original article can be found under doi:10.1007/s40744-016-0035-1.

K. Thakur $(\bowtie) \cdot$ A. Handrich · M. F. Rezk

Biogen International GmbH, Zug, Switzerland

e-mail: Kunal.thakur@biogen.com

A. Biberger

Kantar Health GmbH, Munich, Germany
Open Access. This article is distributed under the terms of the Creative Commons AttributionNonCommercial 4.0 International License (http://creativecommons.org/licenses/by-nc/4. $0 /$ ), which permits any noncommercial use, distribution, and reproduction in any medium, provided you give appropriate credit to the original author(s) and the source, provide a link to the Creative Commons license, and indicate if changes were made. 